\title{
A corpus study of negation and their disnuptive patterns in political discourse
}

Um estudo de corpus sobre a negação e seus padrões disruptivos no discurso político

José Manuel Durán

DOI: $h t t p: / / d x . d o i . o r g / 10.5902 / 2176148531175$

\begin{abstract}
This paper reports the results of a quantitative study on the patterns of negation and their intersections with lexicogrammatical systems in political discourse. The corpus, made up of the 45 inaugural speeches delivered by US presidents $(122,848$ words), was semiautomatically tagged following the theoretical framework of systemic functional linguistics. Results show that the frequency of negation in this register is higher than that in the overall pattern of English. Besides, a recurrent interplay between negation and concession and some discoursal disruptions have been found to be statistically significant. Among them, outstand the intersections of negative polarity and modality, and no-negation and existential processes.
\end{abstract}

Keywords: Negation. Inaugural political speech. Lexicogrammatical disruptions.

Resumo: O presente trabalho dá conta dos resultados de um estudo quantitativo sobre os padrões da negação léxico-gramatical e suas disrupções no discurso político. O corpus, formado pelos discursos pronunciados pelos 45 presidentes estadunidenses no início de seus mandatos (122.848 palavras), foi rotulado semiautomaticamente e analisado no marco teórico da linguística sistêmico-funcional. Os resultados mostram que a frequência da negação neste registro é mais alta do que a do padrão geral do inglês. Foi detectado, além disso, uma interação recorrente entre a negação e a concessão e outras disrupções discursivas que resultaram estatisticamente significativas. Entre elas, destacam-se as intersecções da polaridade negativa e a modalidade, assim como as frequências de negação por meio do determinante no sob o alcance dos processos existenciais.

Palavras-chave: Negação. Discurso político inaugural. Disrupções léxico-gramaticais. 


\section{Introduction}

In the last decades political discourse has increasingly attracted the attention of systemic functional linguists (DURÁN, 2008; KRIZSÁN, 2011; MARTÍNEZ LIROLA, 2012; KAZEMIAN; HASHEMI, 2014; KOUTCHADÉ, 2015; NUR, 2015). While all these works contribute to the intraregisterial characterisation of political speeches and help us understand the way in which political leaders construe meaning, it can be richer to examine a corpus of speeches and to analyse the intersection of lexicogrammatical choices in different (sub)systems present in the language (HALLIDAY, 1991a). If there exists José Manuel a correlation between different grammatical subsystems, and if these Durán correlations remain systematically the same or vary diatopically and/or diatypically, these correlations will better contribute to our understanding of the whole system in language. Alternatively, if the degree of correlation proves to increase diachronically, then these higher degrees of correlation will contribute to our understanding of the evolution of the system of language. There are different ways of analysing these correlations. One possibility would be to investigate different subsystems that are simultaneous - or presumably independent - and intersect the frequency patterns of these subsystems (HALLIDAY, 1991b). A further possibility would be to initially explore subsystem $m$ and see whether its frequency patterns affect those in other subsystems n, o, p, q, etc. This is the methodology chosen in this paper.

The aim of this paper is thus to report the (un)associations of grammatical realisations within different systems available in the language from the perspective of systemic functional linguistics (HALLIDAY; MATTHIESSEN, 2014). In particular the paper focuses on the effects of negative polarity on the systems of the clause and the noun group in a corpus of political inaugural speeches by US presidents. While the system of POLARITY ${ }^{1}$ has been found to be skewed towards positive over negative polarity with a rate 0.9 to 0.1 (HALLIDAY;JAMES, 1993), it has been shown that negative polarity is much higher in this particular register (LAVANDERA; PARDO, 1987; DURÁN, 2017). The paper is organised as follows. Section 2 provides details of the corpus and the methodology applied and section 3 very succinctly summarises the theoretical framework. In section 4 , results are divided into two broad areas, namely clausal negation and nominal negation. Finally, some concluding remarks are given.

1 Here we adopt the tradition within systemic functional linguistics, according to which lexicogrammatical systems are identified in capital letters. 


\section{Theoretical Framework}

Systemic functional linguistics (SFL) is a theory whose focus of study is language as a social system for making meaning. It is functional because SFL places great emphasis on the functions performed by speakers/ writers of the language in their interactions. It is systemic because also great emphasis is placed on the systems from which speakers/writers make choices in their interactions. SFL has developed a tri-stratal model for language analysis. For example, meanings can be studied from above the clause, from below the clause and from beyond the clause. Meanings are also simultaneously created and can be studied from the point of view of three different metafunctions, namely experiential, interpersonal and textual. The theory can hardly be explained in detail in few paragraphs but Eggins (2004) and Thompson (2014) can be

A corpusstudy of negation and their distuptive patternsin political discourse suggested as introductory courses to the so called IFG4, or $4^{\text {th }}$ edition of Introduction to Functional Grammar (HALLIDAY; MATTHIESSEN, 2014).

Here we will only focus on the system of POLARITY. All clauses can be said to be either positive or negative ${ }^{2}$. Thus the paradigmatic choices of clause POLARITY are positive or negative. There exist further options within the system of POLARITY when it is explored at a more delicate level, as is depicted in Figure 1.

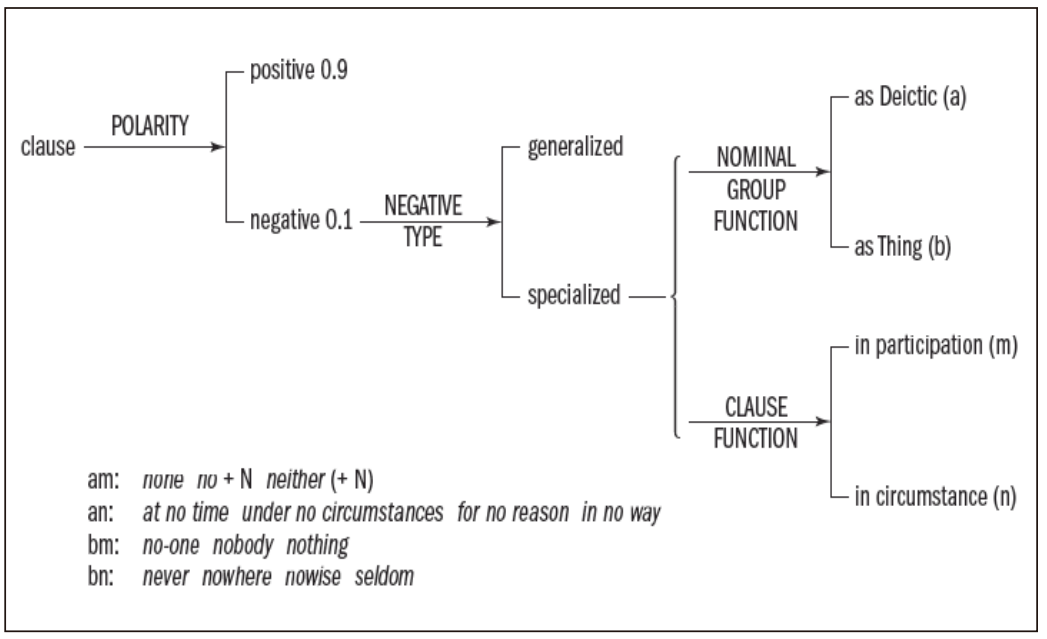

Figure 1: The system of POLARITY

Source: (HALLIDAY; MATTHIESSEN, 2014, p. 23)

2 Patterns of negative polarity in political speeches have extensively been analysed from different discoursal perspectives. See for example García Negroni (2016) and the references therein. 
The probabilities of choices within a certain system are highly sensitive to register (HALLIDAY; MATTHIESSEN, 1999; MATTHIESSEN, 2015). In addition, users of a language make choices from the different systems available in the language, whether from the same or from different metafunctions and corpus studies can help us understand how some systems of the system network intersect.

\section{Corpus and Methodology}

The corpus is made up of all 45 inaugural speeches delivered by US

José Manuel

Durán presidents (122,848 words). This corpus was semi-automatically tagged for all instances of negative polarity with the aid of WordSmithTool and UAM CorpusTool. The first of these tools has helped us identify all instances of negative polarity items such as not, never, no, etc. in the corresponding clauses in which they appear. The second tool allows us to quantify the features of the clauses in the corpus. All clauses with items of negative polarity were pasted onto a spreadsheet file and classified from a traditional perspective together with some SFL features. There followed a quantification process. In order to make figures by different presidents comparable, frequencies per 100 clauses were calculated in the following way. Actual occurrences of negative polarity items were divided by the number of finite clauses found in each speech. Later, filters were applied to focus on specific features. Figure 2 below exhibits a small sample of some of the results obtained. Finally, a chi square test was applied to test the strong dependence of some of the different systems.

\begin{tabular}{|c|c|c|c|c|c|c|c|c|c|c|c|c|c|c|c|c|c|}
\hline 4 & $A$ & B & C & D & $E$ & $F$ & G & $H$ & 1 & J & K & L & M & $\mathrm{N}$ & 0 & $P$ & $Q$ \\
\hline 1 & & & & $\checkmark$ & & & & & & & & & & & & & \\
\hline 2 & & & & & & clauses & words & no & p $100 \mathrm{dl}$ & not & per 100 & $n^{\prime} t$ & per 100 & cannot & per 100 & never & per 100 \\
\hline 3 & & & President & Party & & & & & no & & not & & $n^{\prime} t$ & & cannot & & never \\
\hline 4 & 1 & 1789-1797 & Washington & None & 30 Apr 1789 & 122 & 1430 & 8 & 6,5 & 3 & 2,5 & 0 & 0,0 & 1 & 0,8 & 2 & 1,6 \\
\hline 5 & 2 & 1797-1801 & Adams, J & $\mathrm{F}$ & 4 Mar 1797 & 198 & 2318 & 6 & 3,0 & 16 & 8,1 & 0 & 0,0 & 0 & 0,0 & 1 & 0,5 \\
\hline 6 & 3 & 1801-1809 & Jefferson & DR & 4 Mar 1801 & 147 & 1724 & 1 & 0,7 & 12 & 8,1 & 0 & 0,0 & 0 & 0,0 & 1 & 0,7 \\
\hline 7 & 4 & 1809-1817 & Madison & DR & 4 Mar 1809 & 100 & 1175 & 2 & 2,0 & 10 & 10,0 & 0 & 0,0 & 0 & 0,0 & 1 & 1,0 \\
\hline 8 & 5 & $1817-1825$ & Monroe & DR & 4 Mar 1817 & 288 & 3366 & 5 & 1,7 & 16 & 5,6 & 0 & 0,0 & 1 & 0,3 & 3 & 1,0 \\
\hline 9 & 6 & $1825-1829$ & Adams, JQ & DR & 4 Mar 1825 & 249 & 2912 & 1 & 0,4 & 4 & 1,6 & 0 & 0,0 & 0 & 0,0 & 0 & 0,0 \\
\hline 10 & 7 & 1829-1837 & Jackson & D & 4 Mar 1829 & 96 & 1126 & 2 & 2,1 & 2 & 2,1 & 0 & 0,0 & 0 & 0,0 & 1 & 1,0 \\
\hline 11 & 8 & 1837-1841 & Van Buren & D & 4 Mar 1837 & 328 & 3833 & 7 & 2,1 & $27^{\prime}$ & 8,2 & 0 & 0,0 & 0 & 0,0 & 8 & 2,4 \\
\hline 12 & 9 & 1841 & Harrison & Whig & 4 Mar 1841 & 722 & 8444 & 36 & 5,0 & 54 & 7,5 & 0 & 0,0 & 0 & 0,0 & 13 & 1,8 \\
\hline 13 & 10 & 1841-1845 & Tyler & Whig & 9 Apr 1841 & 143 & 1672 & 7 & 4,9 & 3 & 2,1 & 0 & 0,0 & 0 & 0,0 & 1 & 0,7 \\
\hline 14 & 11 & 1845-1849 & Polk & $D$ & 4 Mar 1845 & 410 & 4802 & 14 & 3,4 & 34 & 8,3 & 0 & 0,0 & 0 & 0,0 & 0 & 0,0 \\
\hline 15 & 12 & 1849-1850 & Taylor & Whig & 5 Mar 1849 & 93 & 1088 & 2 & 2,2 & 5 & 5,4 & 0 & 0,0 & 0 & 0,0 & 0 & 0,0 \\
\hline 16 & 13 & 1850-1853 & Fillmore & Whig & 2 Dec 1850 & 711 & 8322 & 19 & 2,7 & 44 & 6,2 & 0 & 0,0 & 0 & 0,0 & 2 & 0,3 \\
\hline
\end{tabular}

Figure 2: Sample of results

Source: Research results 


\section{Results}

Lexicogrammatical negation can be realised through a number of grammatical words or morphemes such as not, no, never, n't and contrastive and concessive conjunctions and adverbs such as however and although (HALLIDAY; MATTHIESSEN, 2014). For example, (1) to (4) taken from my corpus exhibit instances of negative polarity realised by grammatical words/morphemes present in the Mood element (THOMPSON, 2014). Thus the corresponding mood tag that could have been added would have been (1) have they?, (2) is there?, (3) has there? and (4) do we?, respectively.

1) Their victories have not been your victories. [Trump, 2017]

2) There is no good reason why we should fear the future [...]. [T. Roosevelt, 1905]

Acorpusstudy

of negation and

their disruptive

patternsin

political discourse

3) There has never been any reasonable cause for such apprehension. [Lincoln, 1861]

4) We don't have to talk late in to the night about which form of government is better. [Bush, 1989]

The overall frequencies of grammatical negation are shown in Figure 3 below. Results prove that in this register, grammatical negation is much higher than that present in the overall pattern of English (HALLIDAY; JAMES, 1993), wherein the ratio of negative/positive polarity in an 18 million-word corpus of written text is $0.1: 0.9$, i.e. one out of ten clauses is negatively polarised. Very similar frequencies of negative (8.5\%) vs. positive (91.5\%) polarity are found in the register of interviews (MATTHIESSEN, 2006). Tottie (1991) also reports a similar frequency of negation in written texts (12.8 negative items per 1000 words, which is equivalent to approximately 15 negative items per 100 clauses, i.e., 1.5 out of ten clauses are negatively polarised). By contrast, in the case of inaugural political speeches by US presidents, negative polarity is on average 25.8 per 100 clauses, i.e., 2.58 out of ten clauses are negatively polarised, reaching levels of $47.6 \%, 47.0 \%, 43.7 \%, 42.7 \%$, $41.0 \%$ and $40.9 \%$ in the cases of T. Roosevelt, Bush Jr., Kennedy, Ford, Coolidge and Lincoln, respectively. The other point worth mentioning is the chronological increase over the 228-year time span covered in the corpus, as is shown by the linear trend line in Figure 3. This can be explained by the fact that later US presidents tend to choose more overtly polar expressions in their inaugural speeches than earlier ones, which 
helps them create a higher level of polarisation in American politics to establish their future policies (HETHERINGTON; WEILER, 2009). This higher level of polarisation may stem from the weak executive power with which presidents take office in two-party presidential regimes (MAINWARING, 1993). Thus, inaugural political speeches exhibit both systematically and chronologically higher levels of negation than those in the system of English language.

José Manuel

Durán

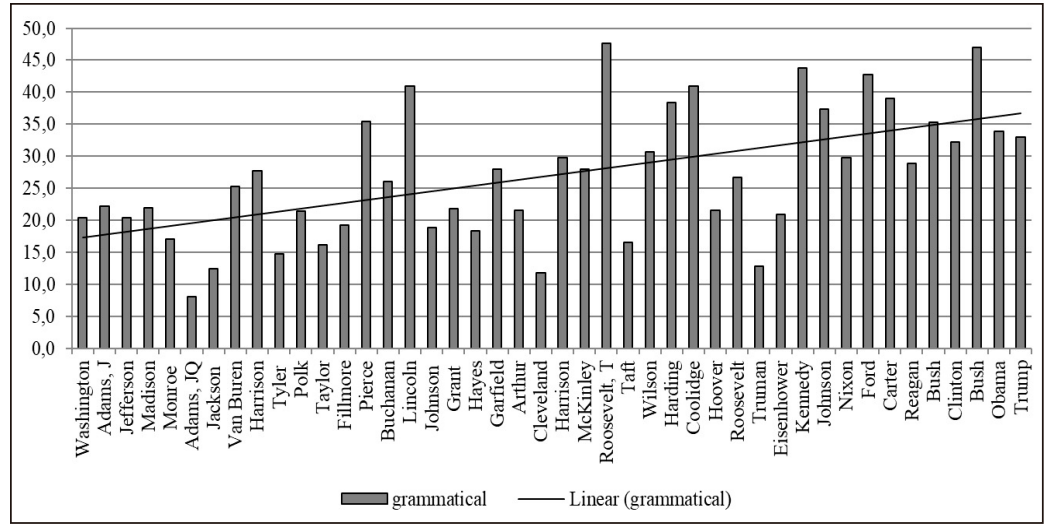

Figure 3: Frequency of grammatical negation items per 100 clauses by speech Source: Research results

Figure 4 exhibits the frequencies of the five most recurrent grammatical negative items chosen by US presidents. Again the patterns shown for individual negatively polar items increase chronologically, which proves that this tendency is not random but systematic.

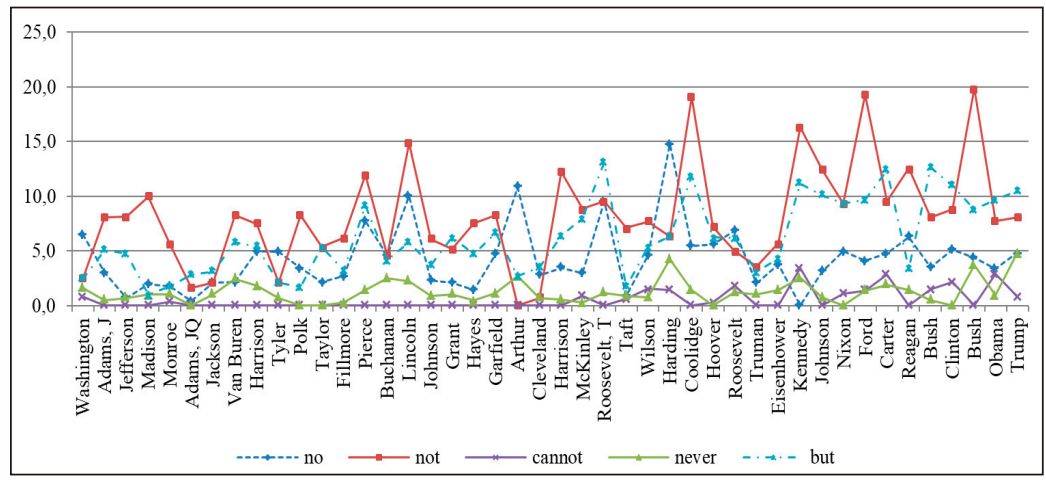

Figure 4: Frequency of 5 polarity items per 100 clauses by speech Source: Research results. 
Yet, there is great variety between occurrences of the most frequent negatively grammatical items, which is shown in Figure 5 below. For example not-negation is twice as frequent as no-negation, which suggests that negation at clause level doubles negation at the level of the noun group. This is in line with the findings in Biber et al. (1999, p. 170), who contrast the frequencies of not and no in four different registers, namely conversation, fiction news, and academic. In all these registers, not-negation outnumbers no-negation with a ratio of 9 to 1,3 to $1,1.9$ to 1 and 3 to 1 , respectively. If we disregard the register of conversation, which is fairly different from all the others in a number of respects (BIBER et al. 1999, p. 12), the register of inaugural political speeches is rather similar to the other three in terms of the not/no distinction. Therefore, it can be suggested that this feature is not necessarily characteristic of the register under study but a feature of the English language as a whole.

\section{Acorpusstudy of negation and their disruptive patternsin political discourse}

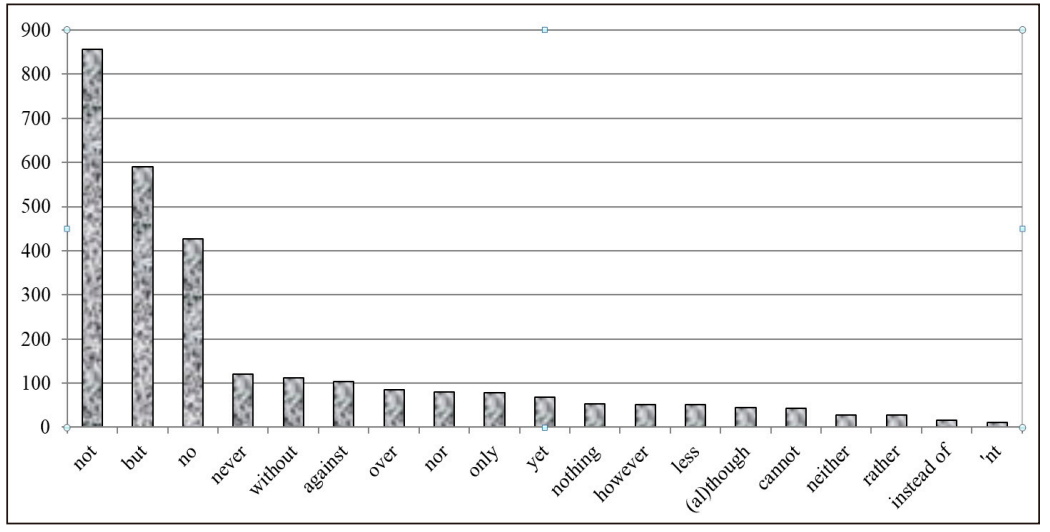

Figure 5: Overall occurrences of grammatical negation items Source: Research results

As can be seen in Figure 5, negation through the particle not-including the attached morpheme in cannot and the reduced form n't - and through the determiner no together cover $47 \%$ of all instances in my corpus. This renders them worthy of analysis, which is the focus of the following subsections.

\subsection{Clausal Negation}

As was mentioned in the previous section, not-negation is by far the most frequent type of negation in the register under study. Still, the word not can have a wide scope over the whole clause or a narrow scope over a constituent of a clause realised by a phrase or group (HUDDLESTON; PULLUM, 2002; MORANTE; LIEKENS; DAELEMANS, 2008). Let us see some examples, wherein 
not has scope over the whole clause in (5), over a prepositional phrase in (6), over an adverbial group in (7), over a noun group in (8), over an adjectival group in (9), and over a pronominal group in (10).

5) A wise and frugal Government [...] shall not take from the mouth of labor the bread it has earned. [Jefferson, 1801]

6) The success of our economy has always depended [...] on the ability to extend opportunity to every willing heart - not out of charity, but because it is the surest route to our common good. [Obama, 2008]

José Manuel

Durán

7) The Navy, not inappropriately termed the right arm of the public defense [...], should be rendered replete with efficiency. [Tyler, 1841]

8) One by one, the factories shuttered and left our shores with not even a thought about the millions and millions of American workers that were left behind. [Trump, 2017]

9) Though not altogether exempt from embarrassments that disturb our tranquillity at home [...] we stand without a parallel in the world. [Van Buren, 1837]

10) Not all of our people are happy and prosperous; not all of them are virtuous and law-abiding. [Harrison, 1889]

The distribution of the grammatical categories over which not has scope can be seen in Figure 6. This shows that clausal negation is far higher than negation in all other more local types taken together, with a frequency of $77 \%$ of all instances. Hence clausal negation can be considered the default pattern. However, this distribution is not a characteristic pattern of the register under study here but rather more plausibly a feature of the English language as a whole.

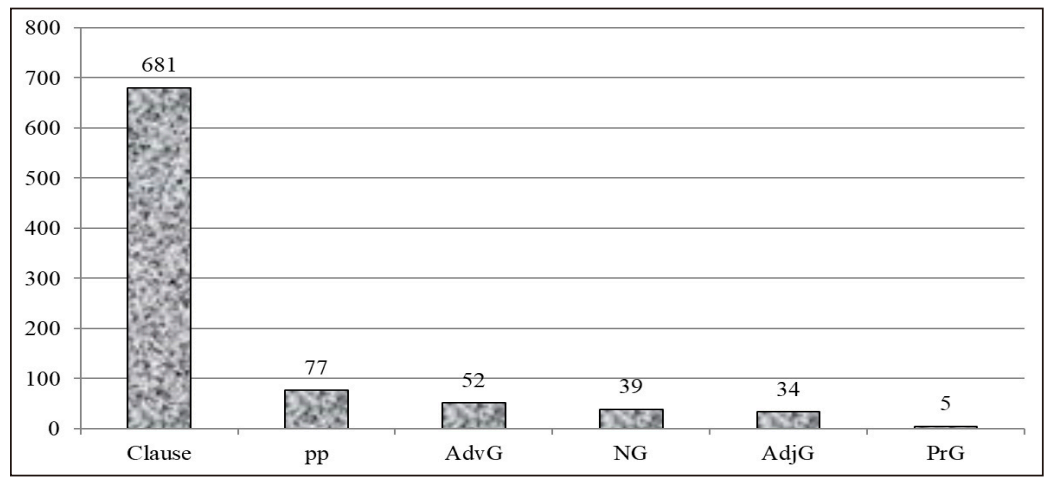

Figure 6: Scope of not Source: Research results 
However, there is a clear pattern that is characteristic of the register inaugural political speeches. This pattern widely exploited by American presidents is the strong interplay between negation and concession/contrast. This occurs overtly both within the local context of a sentence and also in the broader context of a paragraph. For example, in 289 out of the 888 instances of not, this particle appears in the local context of a sentence in a zigzag pattern of (X) but not $Y$ (examples 11 to 14 ) or not $X$ but $Y$ (examples 15 to 20 ).

11) We have been deeply wronged upon the seas, but we have not wished to wrong or injure in return [...] [Wilson, 1913]

12) By the theory of our Government majorities rule, but this right is not an arbitrary or unlimited one. [Polk, 1845]

Acorpusstudy

of negation and

their disruptive

patternsin

political discourse

13) The maintenance of the Union brings with it "the support of the State governments in all their rights," but it is not one of the rights of any State government to renounce its own place in the Union or to nullify the laws of the Union. [Johnson, 1865]

14) We know we have to face hard truths and take strong steps, but we have not done so; instead, we have drifted. [Clinton, 1993]

In examples (11) to (14), wherein but precedes not, the conjunction but is working as a true concessive element that introduces a negative clause which denies an assumption that could have been inferred from the previous clause. This is what Thompson (2005, p. 770) calls situation - cancellation, wherein the but-clause cancels the assumption that could have been inferred from the situation expressed in the previous clause. Thus in (11), President Wilson cancels the assumption of wishing for vengeance that having been wrong could have inferred. In (12), President Polk cancels the assumption of arbitrariness or unlimitedness that could have been interpreted from the principle of rule by the majority. Similarly, in (13) President Johnson cancels the assumption of the right of the State government that could have been inferred from the right that the maintenance of the Union brings. In (14) President Clinton cancels the assumption of a presumed course of action that could have been inferred from awareness that we have to face hard truths and take strong steps.

In examples (15) to (20), however, the pattern is reversed, which is the most frequent of all patterns in inaugural speeches (214 tokens). In these cases, the negative particle not precedes the but-clause/phrase/ 
group. Here the interplay between not and but expresses the strong link of denial and counter (MARTIN; WHITE, 2005; MARTIN; ROSE, 2008), or the logical relation between clauses (WINTER, 1994, p. 54-55), whereby "the expectations are dismissed at the same time as being mentioned" (THOMPSON, 2005, p. 780).

15) So, too, the breakwater at the mouth of the Delaware is erected, not for the exclusive benefit of the States bordering on the bay and river of that name, but for that of the whole coastwise navigation of the United States

José Manuel

Durán and, to a considerable extent, also of foreign commerce. [Fillmore, 1850]

16) We ought to cultivate peace, commerce, and friendship with all nations, and this not merely as the best means of promoting our own material interests, but in a spirit of Christian benevolence toward our fellowmen, wherever their lot may be cast. [Buchanan, 1857]

17) We should look at the national debt just as it is - not as a national blessing, but as a heavy burden on the industry of the country, to be discharged without unnecessary delay. [Johnson, 1865]

18) It was not a presumptuous assurance, but a calm faith, springing from a clear view of the sources of power in a government constituted like ours. [Pierce, 1853]

19) To do so we must show, not merely in great crises, but in the everyday affairs of life [...] [T. Roosevelt, 1901]

20) If the United States be not a government proper, but an association of States in the nature of contract merely, can it, as a contract, be peaceably unmade by less than all the parties who made it? [Lincoln, 1861]

In all these examples, American presidents express that it is not principle $\mathrm{X}$ but principle $\mathrm{Y}$ that will govern their actions in office. In this way, presidents deny a certain assumption or belief and replace it with a new one overtly (GIVÓN, 1978). Thus, in (15) President Fillmore denies that the reason behind the erection of a breakwater is an exclusive benefit and replaces it with a more general benefit in order to cancel a possible assumption or belief. In (16) President Buchanan denies that the reason behind a more global integration is out of selfishness and replaces it with a more religious one in order to cancel a possible assumption or belief that the claim for integration could have underlain. In (17) President Johnson denies that the national debt should be interpreted as beneficial and replaces this assumingly 
plausible interpretation with an explicitly harmful one. In a parallel fashion, President Pierce in (18) denies the principle of assuredness and replaces it with that of faith; President T. Roosevelt in (19) denies the local context of bad times and replaces it with a more systematic reason for a certain action. In (20), President Lincoln strategically adds the devices of conditional clause and rhetorical question to the denialcounter interplay so as to make his argument even more powerful.

Apart from the strong interplay of negation and concession and denial and counter realised by $(X)$ but not $Y$ and not $X$ but $Y$, respectively, wherein the clausal relations are established overtly through the closedset item but, there are frequent instances in which but is omitted and the clausal relation is established lexically, as in examples (21) to (27).

A corpusstudy of negation and their disruptive patternsin political discourse

21) Our Government springs from and was made for the people - not the people for the Government. [Johnson, 1865]

22) In this present crisis, government is not the solution to our problem; government is the problem. [Reagan, 1981]

23) The questions before our country are problems of progress to higher standards; they are not the problems of degeneration. [Hoover, 1929]

24) The object sought was not a thing dreamed of; it was a thing realized. [Pierce, 1853]

25) Happiness lies not in the mere possession of money; it lies in the joy of achievement, in the thrill of creative effort. [Roosevelt, 1933]

26) And so, my fellow Americans: ask not what your country can do for you - ask what you can do for your countrv. [Kennedy, 1961]

27) While a Treasury surplus is not the greatest evil, it is a serious evil. [Harrison, 1889]

In examples (21) to (27) the omission of the conjunction ${ }^{3}$ but is replaced by the lexical repetition of the underlined lexical items, whereby lexical cohesion replaces grammatical cohesion (HALLIDAY; HASAN, 1976; HOEY, 1991). This lexical repetition establishes a structural parallelism between the clauses juxtaposed. In some cases, lexical repetition is reinforced with further lexical chains, such as that established between the nouns solution and problem in (22), the

3 Not in all the previous examples the word but is a conjunction. In examples (18) and (20) but is a preposition, as it introduces a noun group rather than a clause. 
José Manuel

Durán processes - or traditionally verbs - dreamed of and realized in (24), and the gradable adjectives greatest and serious in (27). Additionally, there are structural chains, such as the parallelism of prepositional phrases headed by preposition in complemented by determiner the, qualifying adjectives, nouns and prepositional phrases in (25), and the what-noun clauses in (26). These cohesive devices contribute to the processing of the contrasts expressed (FRAZIER et al., 2007).

In addition to all the grammatical devices mentioned before, which appear intra-sententially, i.e. within a sentence, these devices are fully exploited by politicians beyond the sentence level, very frequently reaching the level of a whole paragraph. This is shown in examples (28) to (30).

28) Now the trumpet summons us again - not as a call to bear arms, though arms we need - not as a call to battle, though embattled we are - but a call to bear the burden of a long twilight strugale, vear in and vear out, "rejoicing in hope, patient in tribulation" - a struagle against the common enemies of man: tyranny, poverty, disease and war itself. [Kennedy, 1961]

29) Now, so there will be no misunderstanding, it's not my intention to do away with government. It is rather to make it work - work with us, not over us; to stand by our side, not ride on our back. Government can and must provide opportunity, not smother it; foster productivity, not stifle it. [Reagan, 1981]

30) To those leaders around the globe who seek to sow conflict, or blame their society's ills on the West - know that your people will judge you on what you can build, not what you destroy. To those who cling to power through corruption and deceit and the silencing of dissent, know that you are on the wrong side of history; but that we will extend a hand if you are willing to unclench your fist. [Obama,2009]

In (28) President Kennedy very skilfully exploits these devices to introduce the most important points that will be the tenets of his presidency. He resorts to the not- $a$-call-to- $X$ / but $a$-call-to- $Y$ contrast to establish the four experiential components that will lead his politics while in office. In (29) President Reagan feels the need to cancel the presupposition that he would dispose of government and replace it with his overt intention to make it more efficient. The interplay of denial and counter is exploited here not only in the cancellation of a presupposed misunderstanding but 
also in the elaboration of his proposal of what government should and should not do. This proposal is underpinned by the lexical contrasts of the processes provide and smother, foster and stifle. Similarly, in (30) President Obama exploits grammatical and lexical contrasts in setting his policy on foreign affairs. Thus, he resorts to the lexical opposition of the processes build and destroy and the lexical repetition of the mental process know in the imperative mood in order to state his position overtly.

All in all, politicians fully and increasingly exploit these patterns of denial and concession and denial and counter as resources of grammatical cohesion, and the patterns of repetition and contrasts as resources of lexical cohesion to make their arguments more powerful and persuasive. Now, let us see how the negative particle not interacts with some additional grammatical features in the subsystems of the clause. A corpusstudy of negation and their disruptive patternsin political discourse First, we will analyse how negative polarity intersects with features of the clause in the inaugural speeches. The results are shown in Figure 7.

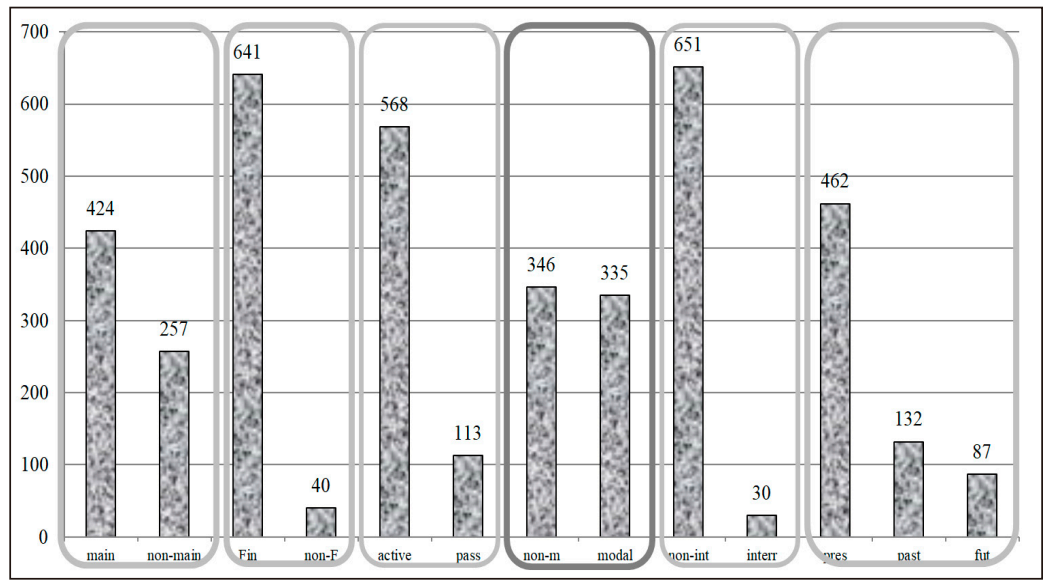

Figure 7: Intersection of negative polarity and clausal features Source: Research results

As can be seen in Figure 7, some patterns of clauses are unaffected by POLARITY. Thus, negatively polarised clauses exhibit highly skewed patterns towards declarative, finite and active $96 \%, 94 \%$ and $83 \%$ of the times, respectively. This distribution is similar to that of the whole pattern of English, wherein declarative clauses are much more frequent than interrogative ones, finite clauses are more frequently chosen than nonfinite ones and active clauses are preferred over passive ones. This suggests that the systems of MOOD, FINITENESS and VOICE are independent of 
José Manuel

Durán
POLARITY. The same holds true for the choice of main over non-main clauses (62\% vs. $38 \%$ ) and for the choice of clauses in the present tense rather than those in the past or future tenses (68\%,19\% and $13 \%$, respectively).

However, the system that is strikingly disrupted by the choice of negative polarity is that of MODALITY. As can be seen in Figure 7, in the case of negatively polarised clauses, modalised/non-modalised clauses exhibit an equiprobable distribution. This is remarkable compared to the findings in the literature. For example, Biber et al (1999, p. 486) obtain that English clauses as a whole are highly skewed towards non-modalised ones (83\% non-modalised vs. $17 \%$ modalised). More specifically, within the register of political discourse, in a corpus of US presidential speeches of 4,429,976 words (AHRENS, 2015), modalised clauses constitute a highly marked choice, with in political speeches favours the choice of modalised clauses.

Still, it is not only the increase of modalised clauses that is favoured by the choice of negatively polarised clauses but also the relative distribution of individual modals that is different from that of the overall pattern in English. This can be seen in Figure 8, which exhibits the occurrences of the modals present in negatively polarised clauses in inaugural speeches. While in Biber et al (1999, p. 486), the most frequent modals are will, would, can and could, in my corpus, first comes modal can, followed by will, should and would. Examples (31) and (32) illustrate instances of negatively polarised clauses modalised by can in a parallel fashion, whereby both Presidents Kennedy and Harding make their guiding principles of what cannot be the case in their policy explicit.

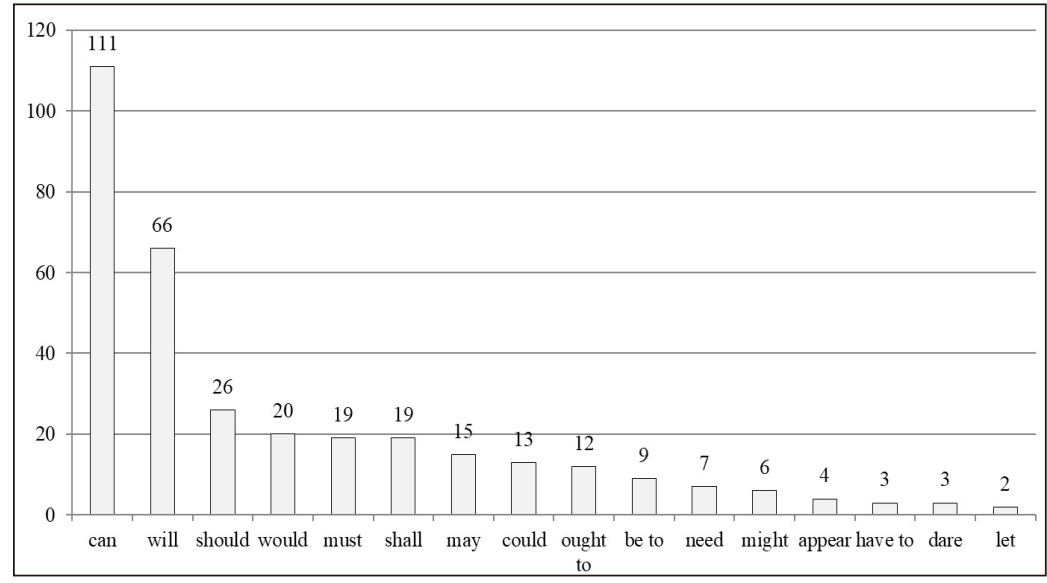

Figure 8: Occurrences of modals in negatively polarized clauses Source: Research results 
31) If a free society cannot help the many who are poor, it cannot save the few who are rich. [Kennedy, 1961]

32) We know full well we cannot sell where we do not buy, and we cannot sell successfully where we do not carry. [Harding, 1921]

What is more, the relative frequency of the eight most recurrent modals in my corpus displays different distributions if we compare the frequencies of individual modals in the negatively polarised clauses with those of individual modals in the whole corpus, whether positively or negatively polarised (Figure 9). As is shown in Figure 9, modal will is the most frequent in all the clauses, which is in line with the pattern found by Biber et al. (1999, p. 486) above mentioned. One of the meanings of the highly polysemous modal will is to show the intention of the speaker/ Acorpusstudy of negation and their disruptive patternsin political discourse writer, also fully exploited by presidents in the whole corpus of clauses in inaugural speeches. Hence, politicians make use of a strong interplay of positively polarised will and negatively polarised can. This can be explained by the fact that while presidents foreground what cannot be the case, they also frequently state what they will do in order for a certain event not to take place, as is depicted in example (33).

33) [...] and for those who seek to advance their aims by inducing terror and slaughtering innocents, we say to you now that our spirit is stronger and cannot be broken; you cannot outlast us, and we will defeat you. [Obama, 2008]

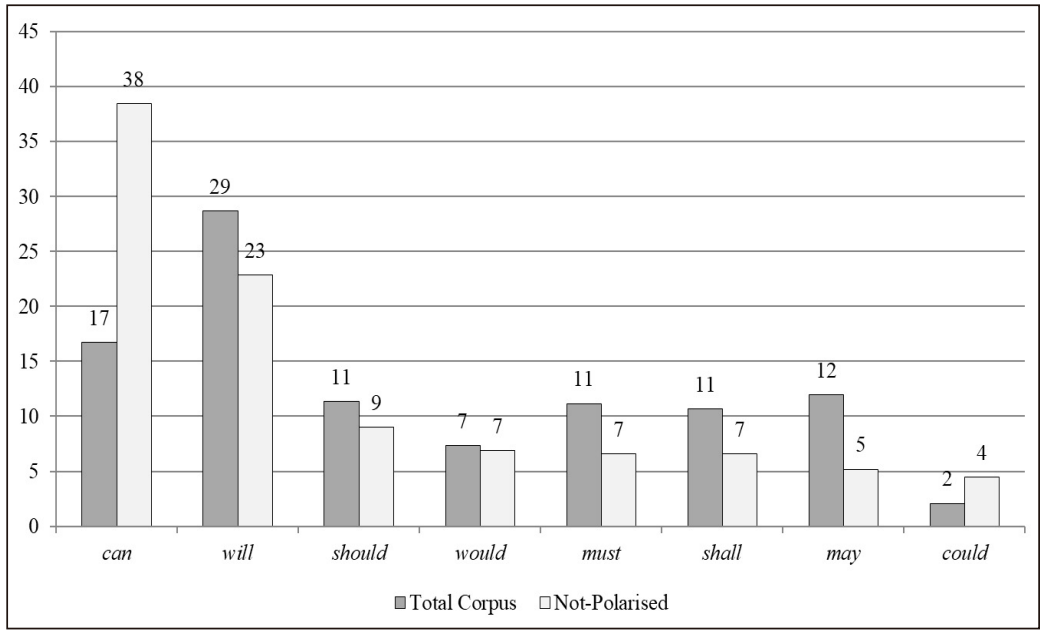

Figure 9: Frequency of 8 modals in the whole corpus and in polarised clauses Source: Research results 
The strong interplay between POLARITY and MODALITY can be statistically proven when we intersect the system of POLARITY with the counts of the two most frequent modals exploited by presidents in their inaugural speeches, namely will and can. This is shown in Table 1, wherein once the chi-square test is applied, the result for $x^{2}$ value is 59.46. This means that at the level of significance 0.001 the choice of modal is strongly dependent on the choice of negatively/positively polarised clauses in inaugural presidential speeches. Therefore, it can be argued that in the register of inaugural political addresses, while positive polarity favours the

José Manuel Durán choice of modal will and disfavours the choice of modal can, negative polarity favours the choice of modal can and disfavours the choice of modal will.

Table 1: Intersection of 2 modals and POLARITY

\begin{tabular}{|c|c|c|c|}
\hline & will & can & T \\
\hline Negatively Polarised & 66 & 111 & $\mathbf{1 7 7}$ \\
\hline Positively Polarised & 731 & 353 & $\mathbf{1 0 8 4}$ \\
\hline $\mathbf{T}$ & $\mathbf{7 9 7}$ & $\mathbf{4 6 4}$ & $\mathbf{1 2 6 1}$ \\
\hline
\end{tabular}

Source: Research results

Finally, a further grammatical system affected by negative polarity in inaugural political speeches that is worth analysing is that of the PROCESS TYPE. Figure 10 exhibits the distribution of verbal processes in negatively polarised clauses. As depicted in Figure 10, material processes in negatively polarised clauses are preferred to all other process types together, with 365 tokens (54\% of all processes). The other percentages are as follows: relational, 30\%; mental, $13 \%$; existential, $1 \%$; verbal, $2 \%$; behavioural, $1 \%$.

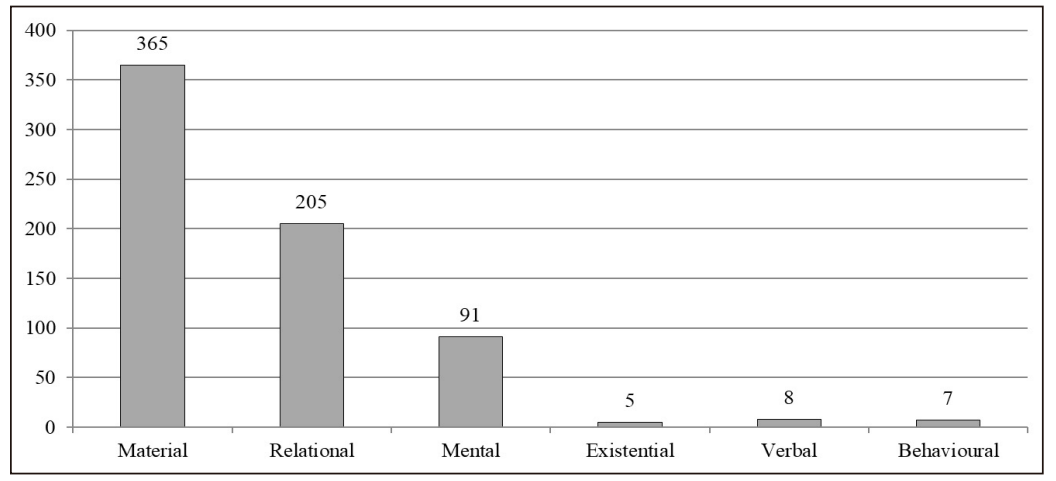

Figure 10: Occurrences of process types in negatively polarized clauses Source: Research results 
While these percentages are different from those in the literature for the overall system of English, there seems to be a higher consensus in the results within the register of political speeches. For example, Matthiessen (2006, p. 126-128) finds that in a corpus of 6525 clauses, material processes appear with a lower frequency in negatively polarised clauses than in their positively polarised counterparts (26\% vs. $34 \%)$. In a larger corpus of 8769 clauses, Matthiessen (2015) finds $39.2 \%$ of material processes with great inter-registerial variation, ranging from $32.1 \%$ to $47.6 \%$. Within the register of political speeches, Durán (2008) finds that politicians make use of higher percentages of material processes (Bush, $4 \%$ and Kerry 38\%), which is in line with the results in Wang (2010), Kazemian and Hashemi (2014), Adjei, Ewusi-Mensah and Okoh (2015) and Adjei and Ewusi-Mensah (2016), who find that material processes reach a level of $58 \%, 52.38 \%, 59.14 \%$ and $45.74 \%$, respectively.

Thus, figures are still not consistent enough to argue that in the particular register of inaugural speeches, the choice of PROCESS TYPE is affected by the choice of negative polarity. What is certain is the fact that US presidents choose in the negatively polarised clauses in their inaugural speeches a high frequency of material processes. In this way, US presidents position themselves as leaders of action who establish the principles that shape and guide their future policies (DURÁN, 2008; WANG, 2010). This can be seen in the following examples.

34) If I do not sink under the weight of this deep conviction [...] [Madison 1809]

35) [W]e now realize [...] that we cannot merely take but we must give as well [...], we must move as a trained and loyal army [Roosevelt, 1933]

36) I do not shrink from this responsibility - I welcome it. [Kennedy 1961]

A further striking difference between my results and those in the literature is the low proportion of mental processes in negatively polarised clauses in my corpus. By contrast, in his intersection of the systems of POLARITY and PROCESS TYPES, Matthiessen (2006) finds a high percentage of mental processes in negatively polarised clauses. He very well explains his results by the fact that "certain mental processes that can serve as metaphorical expressions of modality can occur with a negative transferred from the modalised proposition" (2006, p. 127). While it is true that mental processes participate in this kind of interpersonal grammatical 
metaphor in English, whereby the negative polarity of the projected clause is transferred to the projecting clause (HALLIDAY, MATTHIESSEN, 2014), this pattern only occurs twice in my corpus (examples 37 and 38).

37) The latter is also susceptible of division into power which the majority had the right to grant, but which they do not think proper to intrust to their agents [...]. [Harrison, 1841]

38) Do you not think an angel rides in the whirlwind and directs this storm? [Bush, 1001]

José Manuel

Durán

Apart from the increasingly attested particle not in inaugural speeches, which, as was already stated, has overwhelmingly scope over the whole clause, the negative determiner no is also very frequent in my corpus. Thus the analysis of no-negation is dealt with in the following subsection.

\subsection{Nominal Negation}

Whereas not-negation operates in the more global dominion of the clause, no-negation works in a more local context, the most frequent of which is a noun (89\% of the times), as is depicted in Figure 11. The most frequent collocations with no can be seen in Figure 12, among which are political institutions such as nation, people, power, government and State; arguments for an action such as reason; and incongruent realisations of predication such as doubt, appeal, failure, fear. Some examples are shown below.

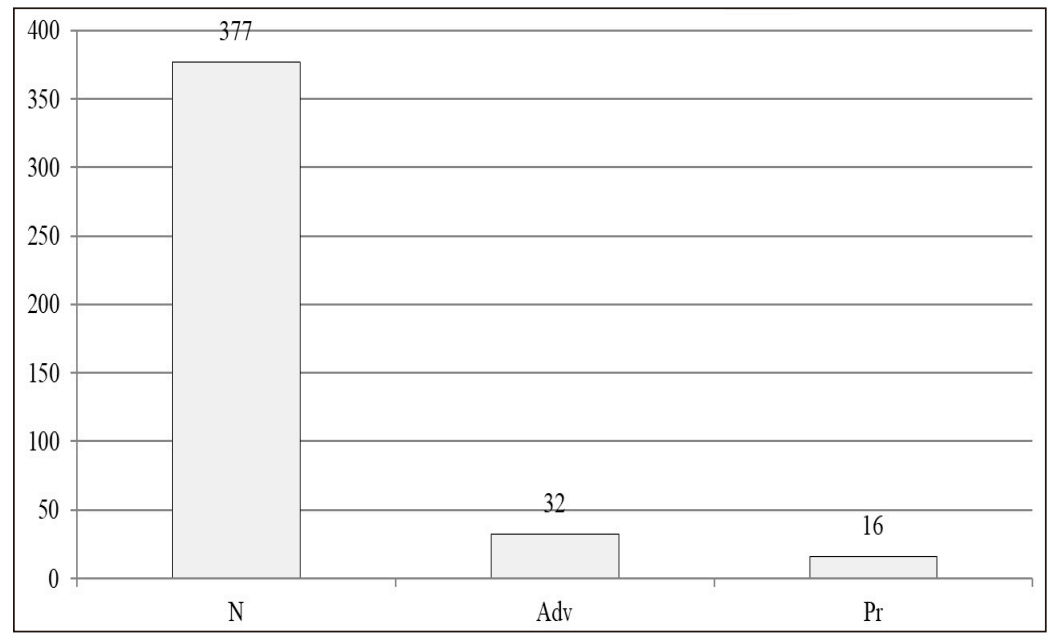

Figure 11: Scope on no Source: Research results 


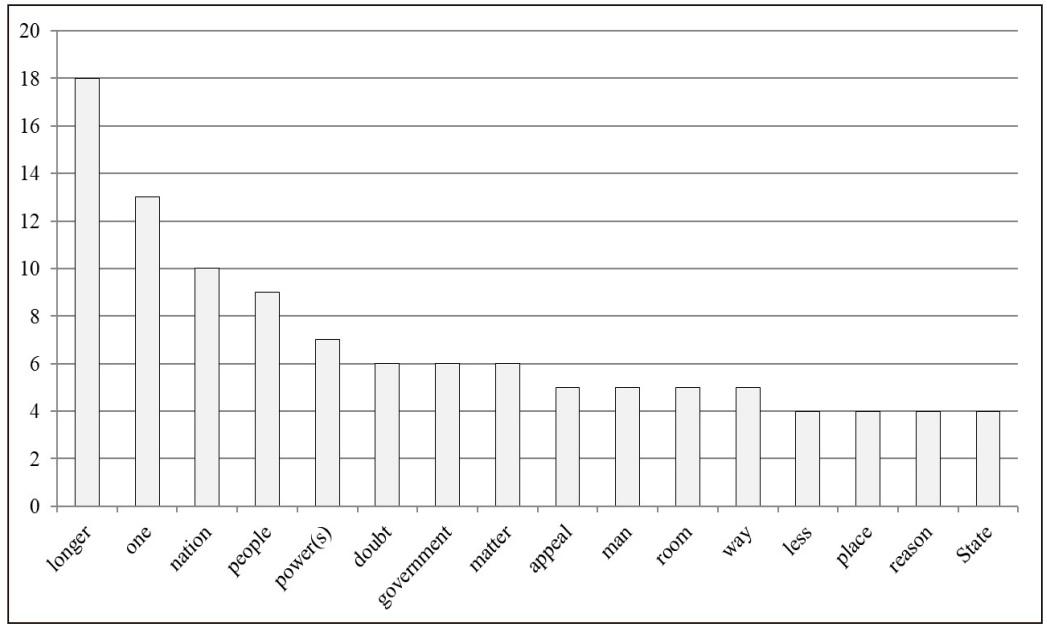

Acorpusstudy

of negation and

their disruptive

patternsin

political discourse

Figure 12: Occurrences of most frequent collations with no

Source: Research results

39) [T]he events of the last four years have established, we will hope forever, that there lies no appeal to force. [Johnson 1865]

40) [...], America is totally unstoppable. There should be no fear. [Trump 2017]

In (39) and (40), no-negation is exploited by Presidents Johnson and Trump, respectively through the so pervasive linguistic strategy of grammatical metaphor. As Halliday (1998) puts it, grammatical metaphor is a process whereby a grammatical class is replaced by another, i.e. it is the reconstrual of experience that is congruently realised for example by a clause into the incongruent realisation of a noun. More congruent realisations of the previous examples would have been The events of the last four years - the Civil War - have established that we should not appeal to force / that we should never go to war again in (39). Similarly, a more congruent realisation of (40) would have been We should not be afraid. Grammatical metaphor is thus a more elaborate transformation than the phenomenon of lexical metaphor, which is attested in political discourse (CHILTON, 2004; CHARTERIS-BLACK, 2005). Chilton's three strategic functions of political discourse have been regarded as the lexical end of Halliday's functions of language (SEMINO, 2008, p. 30-32).

Thus, if no-negation is systematically made use of by politicians as a means of exploiting the linguistic strategy of grammatical metaphor, it is expected that US presidents employ higher levels of the processes more prevailing in expounding registers such as academic reports (MATTHIESSEN, 2015). So let us 
see the distribution of processes in the clauses with realisations of no-negation. This is depicted in Figure 13, wherein for ease of comparison the frequencies of processes in clauses under the scope of not-negation are also shown.

José Manuel

Durán

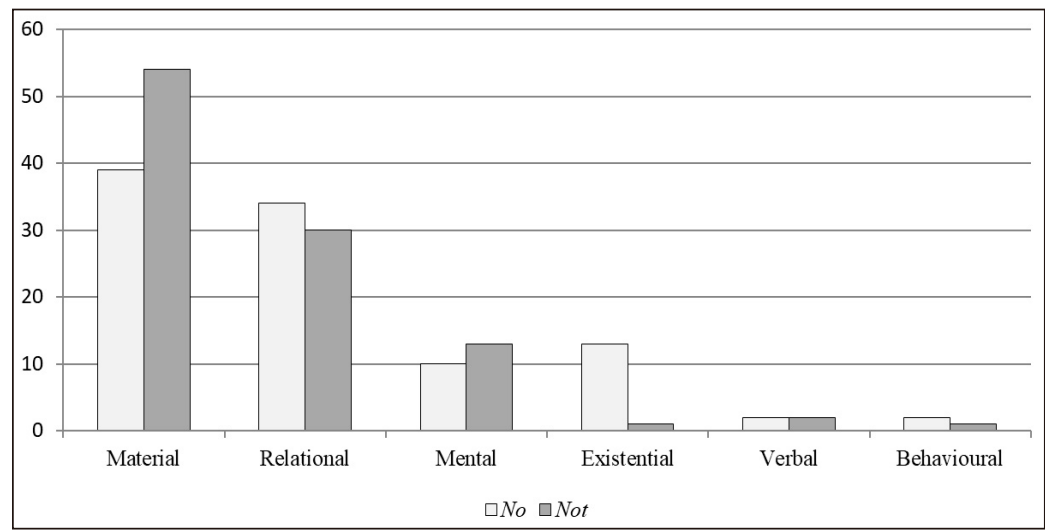

Figure 13: Frequencies of processes under the scope of no / not

Source Research results:

As can be seen in Figure 13, while material and relational processes are still the prevailing ones and verbal and behavioural processes are the least frequent, there are some striking disruptions in the frequencies of the processes. For example, existential processes in clauses that contain no-negation are far more frequent than those that contain not-negation. The former reach a level of $13 \%$ compared to the scarce $1 \%$ of the latter. This increase of existential clauses in no-negation is carried out to the detriment of the frequency of material clauses from $54 \%$ in not-negation to $39 \%$ in no-negation. This is a natural consequence of the lower degree of congruent realisations of negation allowed by clauses with notnegation. This striking contrast is statistically significant, which can be seen in Table 2 below, in which the chi-square result value is $x^{2}=86.65$. This means that at the level of significance 0.001 the choice of PROCESS TYPE is strongly dependent on the choice of negation type.

Table 2: Intersection of 2 process types and negation type

\begin{tabular}{|c|c|c|c|}
\hline & material & existential & $\mathbf{T}$ \\
\hline not-negation & 365 & 5 & $\mathbf{3 6 0}$ \\
\hline no-negation & 167 & 57 & $\mathbf{2 2 4}$ \\
\hline $\mathbf{T}$ & $\mathbf{5 3 2}$ & $\mathbf{6 2}$ & $\mathbf{5 9 5}$ \\
\hline
\end{tabular}

Source: Research results 
The increase of existential processes by the choice of no-negation is accompanied by an increase in relational processes from $30 \%$ to $34 \%$, although this difference is not statistically significant. Some examples of no-negation with material, relational and existential processes are shown in (41), (42) and (43), respectively.

41) I / We can do no less. [Roosevelt 1933 / Clinton 1993]

42) I have no purpose, directly or indirectly, [[to interfere with the institution of slavery in the States [[where it exists]]]]. I believe I have no lawful right [[ to do so]], and I have no inclination [[ to do so]]. [Lincoln, 1861]

43) I add with peculiar satisfaction that there has been no example of a capital punishment [[being inflicted on anyone for the crime of high treason]]. [Monroe, 1817]

Acorpusstudy

of negation and their disruptive patternsin political discourse

As the examples show, no-negation allows politicians to exploit grammatical metaphors, which are packed in nominal groups that are regarded as Things that can in turn be modified by the doublebracketed embedded clauses. A more congruent realisation would have been, for example in (42) I do not intend to [...] and I am not inclined to do so. In this way, presidents strategically present their guiding principles as unquestionable truths and their arguments as objective realities that cannot be challenged.

\section{Concluding Remarks}

As Hasan (2009, p. 22) puts it, "at every stage of human history, [...] politicians have persuaded, and are persuading, their listeners purely through discourse to support some line of action which is designed to bring change in society". At the point of delivering an inaugural speech, American presidents find the need to create a new line of action that brings about some change in society. And one of the ways in which they do so is through discourse. They must orchestrate their speeches so that they can persuade their listeners, and nowadays also viewers around the world. In their inaugural speeches, US presidents coin 'weasel words' (FAIRCLOUGH, 2000), but also exploit the grammatical pole of the lexicogrammatical cline (HALLIDAY; MATTHIESSEN, 2014, p. 64). One of the systems of this lexicogrammatical pole is that of POLARITY, which has been analysed in this paper. 
This paper has shown that US inaugural presidential speeches are noticeably and increasingly biased towards negation. This linguistic strategy is systematically chosen by US presidents who, feeling the need to portray themselves as men of action (DURÁN, 2008), choose an antithetical opponent (ZHOU; KAZEMIAN, 2015) to establish their future policies. With the inauguration of a new presidential period, presidents need to gain power to determine a new course of action, and they do so with a crafted rhetoric of inspirational negativity (BROWN, 2013).

of course, some choices in the patterns of grammatical structures

José Manuel Durán present in a corpus will naturally affect other subsystems at a deeper level of delicacy compared to their overall frequencies in the language. For example, the paper has shown that clausal negation influences the degree of modality to the extent of equiprobable, while no-negation disrupts the frequency of process types. With the more local type of negation affecting the noun group, no-negation, existential processes are increased thirteen times. US presidents resort to this linguistic strategy to put forward more persuasive arguments in their inaugural speeches and to "construe an ostensibly objective discourse that contributes to the reasoning and technical representation of experience," which is characteristic of scientific discourse (DURÁN, 2012, p.116).

From the methodological point of view, in covering all the inaugural speeches by US presidents, I have departed from the pole of instantiation and come closer to the potential pole of the cline (MATTHIESSEN, 2006). More studies like this are needed to cover additional registers so as to more fully comprehend the diatypic variations of the system of POLARITY. Besides, if further intersections between this and other systems are explored, we will be in a better position to redefine the systemic probabilities of the language. Additionally, while every single instance within a linguistic system alters the probabilities of the system in an infinitesimal way, if these changes form a trend, evolution of the system occurs (HALLIDAY, 1991a, p. 45). This paper has shown the systematic evolution of NEGATION in the register of inaugural speeches by the influential US presidents and has thus provided an infinitesimal insight into the evolution of language. The more we linguists become involved in projects that analyse intersections of different skewed subsystems of the language in different registers, the less infinitesimal and the deeper these insights can prove to be. 


\section{References}

ADJEI, A. A.; EWUSI-MENSAH, L. Transitivity in Kufour's 2008 farewell speech to the Ghanaian Parliament. In: British Journal of English Linguistics, Vol.4, No.1, p. 36-49, 2016.

ADJEI, A. A.; EWUSI-MENSAH, L.; OKOH, H. Transitivity in political discourse: A study of the major process types in the 2009 state-ofthe-nation address in Ghana. In: Journal of Literature, Languages and Linguistics, Vol. 16, p. 23-32, 2015.

APEL J, KNOEFERLE P, CROCKER M. W. Processing parallel structure: Evidence from eye-tracking and a computational model. In: VOSNIADOU, S; KAYSER, D; PROTOPAPAS, A (Eds.). Proceedings of Acorpusstudy of negation and their disruptive patternsin political discourse European Cognitive Science Conference. Great Britain: Taylor and Francis, 2007, p. 125-131.

AHRENS, K. Corpus of political speeches. Hong Kong Baptist University Library, 2015. Available at: <http://digital.lib.hkbu.edu. $h k /$ corpus/> Retrieved on: January 20, 2018.

BIBER, D.; JOHANSSON, S.; LEECH, G.; CONRAD, S; FINEGAN, E. Longman grammar of spoken and written English. Harlow, Essex: Longman, 1999.

BROWN, R. E. Varieties of no: Simple, complex, ironic, and poetic negativities in recent U.S. presidential campaigns. In: American Behavioral Scientist 57(12), p. 1731-1737, 2013.

CHARTERIS-BLACK, J. Politicians and rhetoric: The persuasive power of metaphor. Basingstoke: Palgrave Macmillan, 2005.

CHILTON, P. Analysing political discourse: Theory and practice. London: Routledge, 2004.

DURÁN, J. M. The lexicogrammar of negation in US presidents' inaugural speeches. In CHAPPELL, P.; KNOX, J. (Eds.). Transforming Contexts. Wollongong: The Organising Committee of the $44^{\text {th }}$ International Systemic Functional Congress. 2017, p. 40-46. 
. AnSFL analysis of existential clauses in research articles. In: KNOX,J.(Ed.). To boldly proceed: Papers from the $39^{\text {th }}$ International Systemic Functional Congress. Sydney: The Organizing Committee of the $39^{\text {th }}$ ISFC, 2012, p. 111-116.

. The analysis of political discourse applied to Bush's and Kerry's speeches. In: NØRGAARD, N. (Ed.). Systemic functional linguistics in use: Odense working papers in language and communication. Odense: University of Southern Denmark, 2008, p. 267-282.

José Manuel EGGINS, S. An introduction to systemic functional linguistics, Durán $\quad 2^{\text {nd }}$ edition. London and New York: Continuum, 2004.

FAIRCLOUGH, N. New labour, new language? London: Routledge, 2000.

FRAZIER, L. et al. Parallel structure: A source of facilitation in sentence comprehension. In: Memory \& Cognition, 12 (5), p. 421-430, 1984.

GARCÍA NEGRONI, M.M. Discurso político, contradestinación indirecta y puntos de vista evidenciales: La multidestinación en el discurso político revisitada. In ALED 16 (1), 37-59, 2016.

GIVÓN, T. Negation in language: Pragmatics, function, ontology. In: COLE, P. (Ed.). Syntax and Semantics, Vol. 9: Pragmatics. New York: Academic Press, 1978, p. 69-112.

HALLIDAY, M. A. K. Towards probabilistic interpretations. In: VENTOLA, E. (Ed.). Trends in linguistics: functional and systemic linguistics: Approaches and uses. Berlin and New York: Mouton de Gruyter, 1991a. Reprinted in: HALLIDAY, M. A. K. Computational and quantitative studies. Volume 6 in the Collected Works of M.A.K. Halliday, edited by WEBSTER, J. J. London and New York: Continuum, p. 42-62, 2006.

Corpus studies and probabilistic grammar. In: AIJMER, K.; ALTENBERG, B. (Eds.). English corpus linguistics: Studies in honour of Jan Svartvik. London and New York: Longman, 1991b. Reprinted in: HALLIDAY, M. A. K. Computational and quantitative studies. Volume 6 in the Collected Works of M.A.K. Halliday, edited by WEBSTER, J. J. London and New York: Continuum, p. 63-75, 2005. 
. Language and knowledge: The 'unpacking' of text. In: ALLISON, D; WEE, L.; ZHIMING, B.; ABRAHAM, S. A. (Eds.). Text in education and society. Singapore: Singapore University Press and World Scientific, 1998. Reprinted in: HALLIDAY, M. A. K. The language of science studies. Volume 5 in the Collected Works of M.A.K. Halliday, edited by, WEBSTER, J. J. London: Continuum, p. 24-48, 2007.

HALLIDAY, M. A. K.; HASAN, R. Cohesion in English. London: Longman Group. 1976.

Acorpusstudy

of negation and their disruptive patternsin

HALLIDAY, M. A. K.; JAMES, Z. L. A quantitative study of polarity and primary tense in the English finite clause. In SINCLAIR, J. M.; HOEY, M.; FOX, G. (Eds.), Techniques of description: Spoken and political discourse written discourse. London: Routledge, 1993. Reprinted in: HALLIDAY, M. A. K. Computational and quantitative studies. Volume 6 in the Collected Works of M.A.K. Halliday, edited by WEBSTER, J. J. London and New York: Continuum, p. 32-66, 2005.

HALLIDAY, M. A. K.; MATTHIESSEN, C. M. I. M. Construing experience through meaning: A language-based approach to cognition. Malden, New York: Continuum, 1999.

. Halliday's introduction to functional grammar, $4^{\text {th }}$ edition. London: Routledge, 2014.

HASAN, R. Semantic variation: Meaning in society and in sociolinguistics. The collected works of Ruqaiya Hasan, Vol. 2, edited by WEBSTER, J. J. London and Oakville: Equinox, 2009.

HETHERINGTON, M. J.; WEILER, J. Authoritarianism and polarization in American politics. New York: Cambridge University Press, 2009.

HOEY, M. Patterns of lexis in text. Oxford: Oxford University Press, 1991.

HUDDLESTON, R. D.; PULLUM, G. K. The Cambridge grammar of the English language. Cambridge, UK and New York: Cambridge University Press, 2002. 
KAZEMIAN, B.; HASHEMI, S. Critical discourse analysis of Barack Obama's 2012 speeches: Views from systemic functional linguistics and rhetoric. In: Theory and Practice in Language Studies, 4(6), p. 1178-1187, 2014.

KOUTCHADÉ, I. S. Discourse analysis of General Muhammadu Buhari's official acceptance speech: A systemic functional perspective. In: International Journal of English Linguistics, v. 5, N 5, p. 24-36, 2015.

KRIZSÁN, A. The EU is not them but us! The first person plural José Manuel and the articulation of collective identities in European political Durán discourse. Cambridge: Cambridge Scholars Publishing, 2011.

40 LAVANDERA, B. R.; PARDO, M. L. La negación en el discurso político: Patrones y rupturas. In Cuadernos del Instituto de Lingüística, 2, $\mathrm{N}^{\circ}$ 2. Buenos Aires: Instituto de Lingüística, Facultad de Filosofía y Letras, 1987. Reprinted in: LAVANDERA, B. R. Variación y significado. Y discurso. Buenos Aires: Paidós, p. 325-345, 2014.

MAINWARING, S. Presidentialism, multipartism, and democracy: The difficult combination. In: Comparative Political Studies 26(2), p. 198-228, 1993.

MARTIN, J.R; ROSE, D. Working with discourse: Meaning beyond the clause. London and New York: Continuum, 2008.

MARTIN, J.R.; WHITE, P. R. R. The language of evaluation: Appraisal in English. London and New York: Palgrave Macmillan, 2005.

MARTÍNEZ LIROLA, M. The relation of meaning to wording in Mandela's speech of inauguration as President: A systemic functional analysis of rhetorical devices, marked syntax and appraisal. In: Journal of Modern Languages 22, p. 19-31, 2012.

MATTHIESSEN, C. M. I. M. Frequency profiles of some basic grammatical systems: An interim report. In: THOMPSON, G.; HUNSTON, S. System and corpus: Exploring connections. London and Oakville: Equinox, 2006, p. 103-142.

Register in the round: Registerial cartography. In: Functional Linguistics 2, p. 1-49, 2015. 
MORANTE, R.; LIEKENS, A.; DAELEMANS, W. Learning the scope of negation in biomedical texts. In: Proceedings of the Conference on Empirical Methods in Natural Language Processing, EMNLP '08, Honolulu, Hawaii, October 25 - 27, 2008, p.715-724.

NUR, S. Analysis of interpersonal metafunction in public speeches: A case study of Nelson Mandela's presidential inauguration speech. In: The International Journal of Social Sciences, Vol. 30, $\mathrm{N}^{\circ} 1, \mathrm{p}$. 52-63, 2015.

SEMINO, E. Metaphor in discourse. Cambridge: Cambridge University Press, 2008.

Acorpusstudy of negation and their disruptive patternsin political discourse

THOMPSON, G. But me some buts: A multidimensional view of conjunction. In: Text 25(6), p. 763-791, 2005.

Introducing functional grammar, $3^{\text {rd }}$ edition. London and New York, 2014.

TOTTIE, G. Negation in English speech and writing: A study in variation. New York: Academic Press, 1991.

WANG, J. A critical discourse analysis of Barak Obama's speeches. In: Journal of Language Teaching and Research, 1(3), p. 254-261, 2010.

WINTER, E. Clause relations as information structure: Two basic text structures in English. In: COULTHARD, M. (Ed.). Advances in written text analysis. London: Routledge, 1994, p. 46-68.

ZHOU, Q.; KAZEMIAN, B. A rhetorical identification analysis of English political public speaking: John F. Kennedy's inaugural address. In: International Journal of Language and Linguistics, 4(1-1), p. 10-16, 2015.

Recebido em fevereiro de 2018

Aceito em abril de 2018 
